\title{
Gilvimarinus chinensis gen. nov., sp. nov., an agar-digesting marine bacterium within the class Gammaproteobacteria isolated from coastal seawater in Qingdao, China
}

Correspondence Guan-Jun Chen guanjun@sdu.edu.cn

\author{
Zong-Jun Du, ${ }^{1}$ De-Chao Zhang, ${ }^{2}$ Song-Nian Liu, ${ }^{1}$ Ji-Xiang Chen, ${ }^{2}$ \\ Xiang-Li Tian, ${ }^{2}$ Zhi-Nan Zhang, ${ }^{2}$ Hong-Can Liu ${ }^{3}$ and Guan-Jun Chen ${ }^{1,4}$ \\ ${ }^{1}$ College of Marine Science, Shandong University at Weihai, Weihai 264209, PR China \\ ${ }^{2}$ Division of Life Science and Technology, Ocean University of China, Qingdao 266003, PR China \\ ${ }^{3}$ China General Microbiological Culture Collection Center and State Key Laboratory of Microbial \\ Resources, Institute of Microbiology, Chinese Academy of Sciences, Beijing 100101, PR China \\ ${ }^{4}$ State Key Laboratory of Microbial Technology, Shandong University, Jinan 250100, PR China
}

\begin{abstract}
A taxonomic study was performed on strain $\mathrm{OM} 42^{\top}$, which was isolated from coastal seawater from an aquaculture site near Qingdao, China. Phylogenetic analysis based on 16S rRNA gene sequences showed that strain $\mathrm{QM} 42^{\top}$ was a member of the class Gammaproteobacteria. Cells of strain $\mathrm{QM} 42^{\top}$ were Gram-negative, yellow, aerobic and rod-shaped. The strain formed a distinct phyletic line with less than $91 \% 16 \mathrm{~S}$ rRNA gene sequence similarity to its closest relatives with validly published names within the class Gammaproteobacteria. The genomic DNA G +C content was $51.9 \mathrm{~mol} \%$. The major fatty acids were $\mathrm{C}_{16: 1} \omega 7 \mathrm{c} /$ iso- $\mathrm{C}_{15: 0} 2-\mathrm{OH}, \mathrm{C}_{18: 1} \omega 7 \mathrm{c}$ and $\mathrm{C}_{16: 0}$. Based on data from a polyphasic chemotaxonomic, physiological and biochemical study, strain $\mathrm{QM} 42^{\top}$ is considered to represent a novel genus and species, for which the name Gilvimarinus chinensis gen. nov., sp. nov., is proposed. The type strain is $\mathrm{OM}^{\mathrm{T}} 2^{\top}$ (=CGMCC $1.7008^{\top}=\mathrm{DSM}$ $\left.19667^{\top}\right)$.
\end{abstract}

During the past few years, there has been an increase in the isolation and description of novel marine and freshwater bacteria and many novel isolates represent members of the class Gammaproteobacteria, which constitutes one of the dominant bacterial groups in marine environments. Several members produce hydrolytic enzymes that break down agar (Romanenko et al., 2003; Kurahashi \& Yokota, 2004; Yong et al., 2007). The aim of this study was to describe a novel agar-digesting marine bacterium isolated from coastal seawater from an aquaculture site near Qingdao, China. It differed from representatives of known genera within the class Gammaproteobacteria and, thus, a new genus and novel species, Gilvimarinus chinensis gen. nov., sp. nov., is proposed to accommodate this strain.

In the course of screening agar-degrading micro-organisms present in a variety of natural resources near Qingdao, a yellow, Gram-negative and rod-shaped bacterial strain (designated $\mathrm{QM}^{\mathrm{T}}{ }^{\mathrm{T}}$ ) was isolated. The bacteria were isolated by plating $0.1 \mathrm{ml}$ diluted seawater on marine 2216 agar plates (MA; Difco). The plates were incubated

The GenBank/EMBL/DDBJ accession number for the 16S rRNA gene sequence of strain $\mathrm{OM} 42^{\top}$ is $\mathrm{DQ} 822530$. aerobically at $28{ }^{\circ} \mathrm{C}$. After $3-7$ days of inoculation on MA, colonies that formed pits or shallow craters around them were picked and purified by streaking on fresh MA plates at $28{ }^{\circ} \mathrm{C}$. Strain $\mathrm{QM} 42^{\mathrm{T}}$ was obtained as a pure culture after three successive transfers to fresh agar medium and was stored at $-80{ }^{\circ} \mathrm{C}$ in $20 \%(\mathrm{v} / \mathrm{v})$ glycerol.

For phenotypic tests, strain QM42 ${ }^{\mathrm{T}}$ was grown on MA for $48 \mathrm{~h}$ at $28{ }^{\circ} \mathrm{C}$ and the cells were suspended in saline for use as an inoculum. Cell morphology was examined under a light microscope (BX51; Olympus). Colony morphology was observed on MA plates after incubation at $28{ }^{\circ} \mathrm{C}$ for $2-$ 3 days. Tolerance of 3,5,7 and $10 \%(\mathrm{w} / \mathrm{v}) \mathrm{NaCl}$ was assessed on appropriately modified tryptone soy agar (Oxoid). Growth in the absence of $\mathrm{NaCl}$ was assessed on plate count agar (PCA; Oxoid). Inoculated plates were incubated at $28{ }^{\circ} \mathrm{C}$ for up to 5 days. The effects of various temperatures on growth were assessed on tryptone soy agar plates supplemented with $1.0 \%(\mathrm{w} / \mathrm{v}) \mathrm{NaCl}$ and incubated at $4,10,15,28,30,37,40$ and $50{ }^{\circ} \mathrm{C}$. Motility was assessed using a semi-solid medium prepared according to MacFaddin (1976). The tube was incubated at $25{ }^{\circ} \mathrm{C}$ for 5 days. The reduction of nitrate was assessed in nitrate broth, prepared according to the method of Cowan \& Steel 
(1974), and incubated at room temperature for 10 days. Oxidase and catalase activities were determined by using standard methods. Routine tests, such as Gram staining and agarase, amylase, urease, catalase, gelatinase and oxidase activities, were carried out as described by Smibert \& Krieg (1994). The isolates were further tested for their ability to oxidize various carbon sources using Gram-negative MicroPlates (Biolog), according to the manufacturer's instructions. Data were analysed using the software package provided by Biolog. Acid production from carbohydrates was determined as described by Leifson (1963).

Antibiotic sensitivity was assessed as follows: a cell suspension $\left(\sim 10^{7}\right.$ cells $\left.\mathrm{ml}^{-1}\right)$ was swabbed over the surface of Iso-Sensitest agar (Oxoid) plates supplemented with $3 \%$ $(\mathrm{w} / \mathrm{v}) \mathrm{NaCl}$ to create a uniform lawn before aseptic placement of antibiotic discs onto the agar surface. The inoculated plates were incubated overnight at $28{ }^{\circ} \mathrm{C}$.

DNA was extracted and purified as described by Sambrook et al. (1989). The 16S rRNA gene was amplified by PCR with two universal primers (Zhang et al., 2006). The PCR product was sequenced by using an ABI BigDye3.1 Sequencing kit (Applied BioSystems) and an automated DNA sequencer (model ABI3730; Applied Biosystems). The neighbour-joining phylogenetic tree (Fig. 1) was constructed using the Kimura two-parameter and pairwise-deletion model analysis implemented in the program MEGA version 3.0 (Kumar et al., 2004). The nearly complete 16S rRNA gene sequence of strain QM42 ${ }^{\mathrm{T}}$ (1442 bp) was submitted to GenBank/EMBL/DDBJ to search for similar sequences using the BLAST algorithm. The resultant tree topologies were evaluated by bootstrap analysis based on 1000 replicates. Phylogenetic analyses performed with partial and almost complete sequences of members of closely related genera showed that no sequence available in the GenBank database exhibited more than $91 \%$ similarity and strain QM42 ${ }^{\mathrm{T}}$ was placed in the class Gammaproteobacteria and clustered with the genus Microbulbifer. This toplogy was also supported by using the maximum-parismony and minimum-evolution algorithms (data not shown).

The morphological and biochemical data for strain QM42 ${ }^{\mathrm{T}}$ are given in the species description. The phenotypic features that differentiate strain QM42 ${ }^{\mathrm{T}}$ from its closest phylogenetic relatives are given in Table 1.

The $\mathrm{G}+\mathrm{C}$ content of the DNA of strain QM42 ${ }^{\mathrm{T}}$ was determined directly by using HPLC, according to the method described by Tamaoka \& Komagata (1984) and Mesbah et al. (1989). The DNA was hydrolysed with P1 nuclease and the nucleotides were dephosphorylated with bovine alkaline phosphatase (Mesbah et al., 1989). The resulting deoxyribonucleosides were analysed using a Shimadzu HPLC system (Shimadzu). The analytical column used was a VYDAC 201SP54, $\mathrm{C}_{18}(250 \times 4.6 \mathrm{~mm})$ equipped with a guard column 201GD54H (Vydac). Purified nonmethylated lambda phage DNA (Sigma) was used as a control. The DNA G $+\mathrm{C}$ content was calculated from the ratio of deoxyguanosine $(\mathrm{dG})$ and thymidine $(\mathrm{dT})$, according to the method of Mesbah et al. (1989). Cellular fatty acids were determined using a culture grown on MA at $28{ }^{\circ} \mathrm{C}$ for 3 days, and were extracted, methylated and

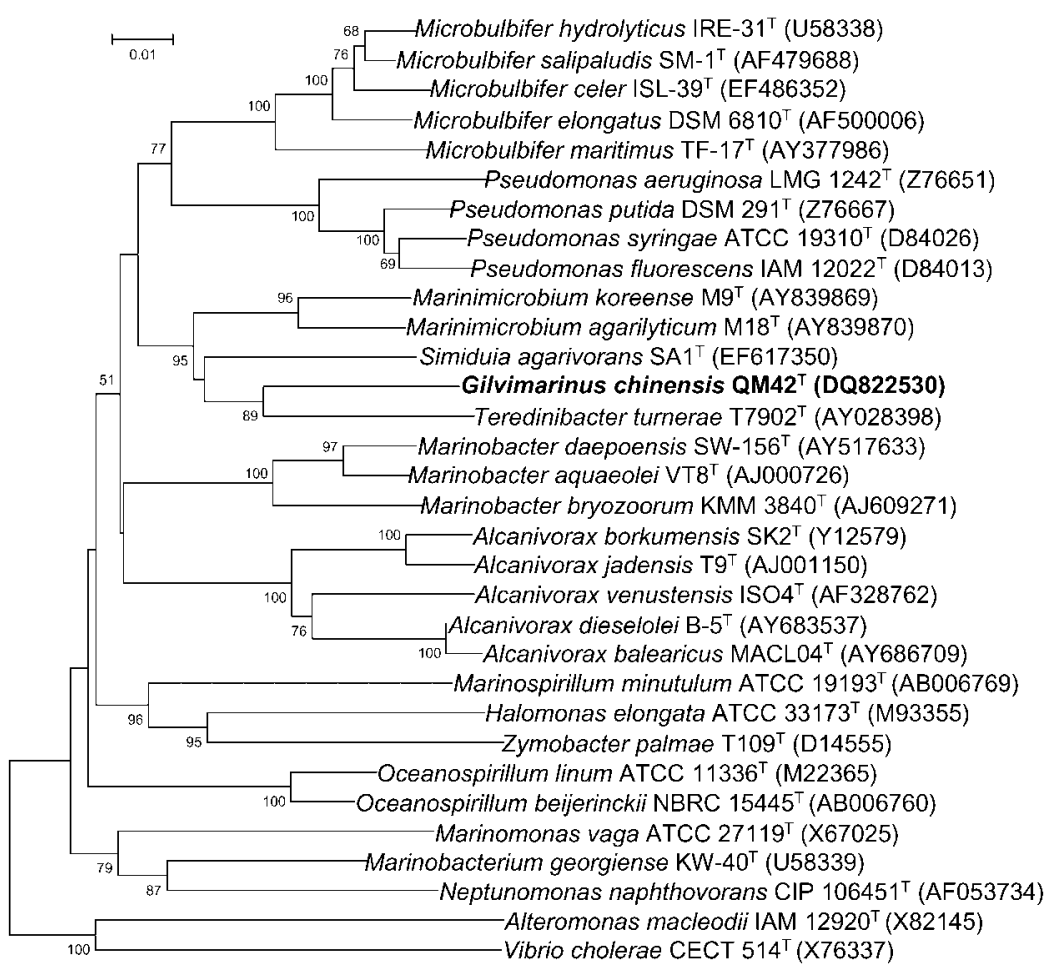

Fig. 1. Phylogenetic dendrogram of Gilvimarinus chinensis gen. nov., sp. nov. and other members of the class Gammaproteobacteria based on 16S rRNA gene sequences. The tree was constructed using the neighbour-joining method. Numbers at nodes are percentage levels of bootstrap support based on a neighbour-joining analysis of 1000 resampled datasets. GenBank accession numbers are given in parentheses. Bar, $1 \%$ sequence divergence. 
Table 1. Comparison of strain $\mathrm{QM} 42^{\top}$ with phylogenetically related genera within the class Gammaproteobacteria

Taxa: 1, strain QM42 ${ }^{\mathrm{T}}$ (Gilvimarinus chinensis gen. nov., sp. nov.); 2, Microbulbifer (data from González et al., 1997); 3, Alcanivorax (Yakimov et al., 1998); 4, Marinobacter (Gauthier et al., 1992; Márquez \& Ventosa, 2005). +, Positive; -, negative; ND, no data available.

\begin{tabular}{|c|c|c|c|c|}
\hline Characteristic & 1 & 2 & 3 & 4 \\
\hline Motility & + & - & - & - \\
\hline \multicolumn{5}{|l|}{ Growth temperature $\left({ }^{\circ} \mathrm{C}\right)$} \\
\hline Optimum & $28-30$ & 37 & $25-30$ & 32 \\
\hline Nitrate reduction & - & ND & + & + \\
\hline \multicolumn{5}{|l|}{ Hydrolysis of: } \\
\hline Agar & + & - & - & $\mathrm{ND}$ \\
\hline Urea & + & $\mathrm{ND}$ & - & - \\
\hline Major fatty acids & $\begin{array}{c}\mathrm{C}_{16: 1} \omega 7 c / \text { iso- } \mathrm{C}_{15: 0} 2-\mathrm{OH}, \\
\mathrm{C}_{18: 1} \omega 7 c, \mathrm{C}_{16: 0}\end{array}$ & $\begin{array}{c}\mathrm{i}-\mathrm{C}_{15: 0}, \mathrm{i}-\mathrm{C}_{17: 1} \omega 9 c, \mathrm{i}-\mathrm{C}_{11: 0} \\
3-\mathrm{OH}\end{array}$ & $\mathrm{C}_{18: 1}, \mathrm{C}_{16: 0}, \mathrm{C}_{16: 1}$ & $\begin{array}{c}\mathrm{C}_{16: 0}, \mathrm{C}_{18: 1} \omega 9 c, \mathrm{C}_{12: 0} \\
3-\mathrm{OH}\end{array}$ \\
\hline DNA G $+C$ content $(\mathrm{mol} \%)$ & 51.9 & 57.7 & 53.4 & 57.3 \\
\hline
\end{tabular}

analysed using the standard MIDI (Microbial Identification) system (Sasser, 1990). The genomic DNA G $+\mathrm{C}$ content was $51.9 \mathrm{~mol} \%$. The cellular fatty acids were $\mathrm{C}_{16: 1} \omega 7 c /$ iso- $\mathrm{C}_{15: 0}$ 2-OH (29.11\%), $\mathrm{C}_{18: 1} \omega 7 c(19.62 \%), \mathrm{C}_{16: 0}(19.53 \%), \mathrm{C}_{18: 0}$ $(10.78 \%), \mathrm{C}_{12: 0}(7.56 \%), \mathrm{C}_{10: 0} 3-\mathrm{OH}(3.53 \%), \mathrm{C}_{12: 0} 3-$ $\mathrm{OH}(3.27 \%), \mathrm{C}_{12: 0} 2-\mathrm{OH}(2.31 \%), \mathrm{C}_{14: 0}(1.89 \%)$ and $\mathrm{C}_{17: 0}(1.09 \%)$.

On the basis of the phylogenetic, chemotaxonomic and taxonomic data from this study, strain $\mathrm{QM} 42^{\mathrm{T}}$ is considered to represent a new genus and novel species within the class Gammaproteobacteria, for which the name Gilvimarinus chinensis gen. nov., sp. nov. is proposed.

\section{Description of Gilvimarinus gen. nov.}

Gilvimarinus (Gil.vi.ma.ri'nus. L. adj. gilvus faint yellow; L. adj. marinus referring to the sea; Gilvimarinus belonging to or living in the Yellow Sea).

Gram-negative, motile, non-spore-forming, rod-shaped and not sensitive to the vibriostatic agent O/129. Cells are oxidase- and catalase-positive. $\mathrm{NaCl}$ is required for growth. The type species is Gilvimarinus chinensis.

\section{Description of Gilvimarinus chinensis sp. nov.}

Gilvimarinus chinensis (chi.nen'sis. N.L. masc. adj. chinensis pertaining to China, where the type strain was isolated).

In addition to the properties given in the genus description, the species is characterized as follows. Cells are $1.5-2.5 \mu \mathrm{m}$ in length and $0.6-0.7 \mu \mathrm{m}$ in width. Colonies are pale yellow, smooth, circular and low convex with entire margins and 1.0 $2.5 \mathrm{~mm}$ in diameter on MA. Growth occurs at $4-40{ }^{\circ} \mathrm{C}$, with optimum growth at $28-30{ }^{\circ} \mathrm{C}$. Growth occurs in the presence of $1-10 \%(\mathrm{w} / \mathrm{v}) \mathrm{NaCl}$. Grows well at $\mathrm{NaCl}$ concentrations of $3-8 \%$, with optimum growth at $5 \% \mathrm{NaCl}$. Nitrate is not reduced to nitrite. Simmons' citrate, Voges-Proskauer test, arginine dihydrolase and gelatinase are negative. Urease, agarase, chitinase and amylase are positive. The following substrates are utilized as sole carbon sources: glucose, dextrin, cellobiose, D-galactose, gentiobiose, maltose, D-mannose, melibiose, methyl $\beta$-D-glucoside, trehalose, turanose and $\mathrm{L}-$ glutamic acid. The following substrates are not utilized as sole carbon sources: D-arabitol, erythritol, L-fucose, inositol, Dmannitol, raffinose, L-rhamnose, D-sorbitol, sucrose, xylitol, L-threonine, L-serine, D-serine, L-leucine and L-phenylalanine. Acids are produced from glucose, xylose, lactose and cellobiose. Acids are not produced from mannose, galactose, fructose, rhamnose, arabinose, dulcitol, inositol, sucrose or trehalose. Sensitive to chloramphenicol, gentamicin, penicillin G, ampicillin, carbenicillin, erythromycin, norfloxacin and amikacin, but resistant to sulfamethoxazole and O/129. Major cellular fatty acids are $\mathrm{C}_{16: 1} \omega 7 c$ /iso- $\mathrm{C}_{15: 0} 2-\mathrm{OH}, \mathrm{C}_{18: 1} \omega 7 c$ and $\mathrm{C}_{16: 0}$. The genomic DNA G $+\mathrm{C}$ content of the type strain is $51.9 \mathrm{~mol} \%$ (determined by HPLC).

The type strain, QM42 ${ }^{\mathrm{T}} \quad$ (=CGMCC $1.7008^{\mathrm{T}}=\mathrm{DSM}$ $19667^{\mathrm{T}}$ ), was isolated from coastal seawater from an aquaculture site near Qingdao, China.

\section{Acknowledgements}

This work was supported by the National Science Foundation of China (Project nos. 40730847, 30500384), Special Non-profit Research Project from Ministry of Agriculture of the People's Republic of China (nyhyzx 07-046). Our thanks are also due to Dr Peter Schumann, Dr Susanne Verbarg, Dr Brian Tindall, DSMZDeutsche Sammlung von Mikroorganismen und Zellkulturen GmbH (German Collection of Microorganisms and Cell Cultures), for their kind help in the identification work.

\section{References}

Cowan, S. T. \& Steel, K. J. (1974). Bacterial characters and characterization. In Cowan and Steel's Manual for the Identification of Medical Bacteria, 2nd edn. Revised by S. T. Cowan. Cambridge, UK: Cambridge University Press. 
Gauthier, M. J., Lafay, B., Christen, R., Fernandez, L., Acquaviva, M., Bonin, P. \& Bertrand, J.-C. (1992). Marinobacter hydrocarbonoclasticus gen. nov., sp. nov., a new, extremely halotolerant, hydrocarbondegrading marine bacterium. Int J Syst Bacteriol 42, 568-576.

González, J. M., Mayer, F., Moran, M. A., Hodson, R. E. \& Whitman, W. B. (1997). Microbulbifer hydrolyticus gen. nov., sp. nov., and Marinobacterium georgiense gen. nov., sp. nov., two marine bacteria from a lignin-rich pulp mill waste enrichment community. Int J Syst Bacteriol 47, 369-376.

Kumar, S., Tamura, K. \& Nei, M. (2004). MEGA3: integrated software for Molecular Evolutionary Genetics Analysis and sequence alignment. Brief Bioinform 5, 150-163.

Kurahashi, M. \& Yokota, A. (2004). Agarivorans albus gen. nov., sp. nov., a $\gamma$-proteobacterium isolated from marine animals. Int $J$ Syst Evol Microbiol 54, 693-697.

Leifson, E. (1963). Determination of carbohydrate metabolism of marine bacteria. J Bacteriol 85, 1183-1184.

MacFaddin, J. F. (1976). Biochemical Tests for Identification of Medical Bacteria. Baltimore, MD: Williams \& Wilkins.

Márquez, M. C. \& Ventosa, A. (2005). Marinobacter hydrocarbonoclasticus Gauthier et al. 1992 and Marinobacter aquaeolei Nguyen et al. 1999 are heterotypic synonyms. Int J Syst Evol Microbiol 55, 1349 1351.

Mesbah, M., Premachandran, U. \& Whitman, W. B. (1989). Precise measurement of the $\mathrm{G}+\mathrm{C}$ content of deoxyribonucleic acid by high-performance liquid chromatography. Int J Syst Bacteriol 39, 159167.
Romanenko, L. A., Zhukova, N. V., Rohde, M., Lysenko, A. M., Mikhailov, V. V. \& Stackebrandt, E. (2003). Glaciecola mesophila sp. nov., a novel marine agar-digesting bacterium. Int $J$ Syst Evol Microbiol 53, 647-651.

Sambrook, J., Fritsch, E. F. \& Maniatis, T. (1989). Molecular Cloning: a Laboratory Manual, 2nd edn. Cold Spring Harbor, NY: Cold Spring Harbor Laboratory.

Sasser, M. (1990). Identification of bacteria by gas chromatography of cellular fatty acids, MIDI Technical Note 101. Newark, DE: MIDI Inc.

Smibert, R. M. \& Krieg, N. R. (1994). Phenotypic characterization. In Methods for General and Molecular Microbiology, pp. 607-654. Edited by P. Gerhardt, R. G. E. Murray, W. A. Wood \& N. R. Krieg. Washington, DC: American Society for Microbiology.

Tamaoka, J. \& Komagata, K. (1984). Determination of DNA base composition by reversed-phase high-performance liquid chromatography. FEMS Microbiol Lett 25, 125-128.

Yakimov, M. M., Golyshin, P. N., Lang, S., Moore, E. R. B., Abraham, W. R., Lünsdorf, H. \& Timmis, K. N. (1998). Alcanivorax borkumensis gen. nov., sp. nov., a new, hydrocarbon-degrading and surfactant producing marine bacterium. Int J Syst Bacteriol 48, 339-348.

Yong, J.-J., Park, S.-J., Kim, H.-J. \& Rhee, S.-K. (2007). Glaciecola agarilytica sp. nov., an agar-digesting marine bacterium from the East Sea, Korea. Int J Syst Evol Microbiol 57, 951-953.

Zhang, D.-C., Yu, Y., Chen, B., Wang, H.-X., Liu, H.-C., Dong, X.-Z. \& Zhou, P.-J. (2006). Glaciecola psychrophila sp. nov., a novel psychrophilic bacterium isolated from the Arctic. Int J Syst Evol Microbiol 56, 2867-2869. 